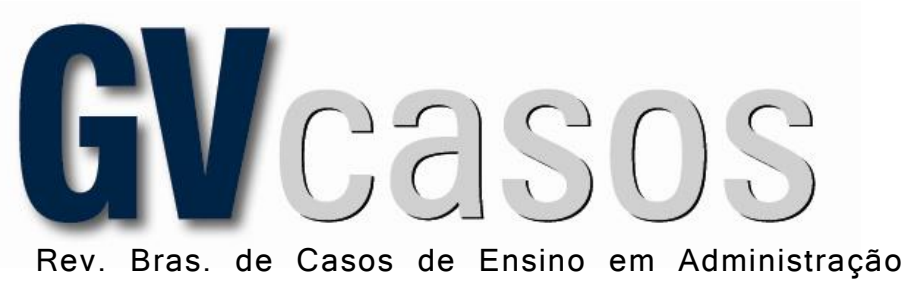

Volume 3

Número 1

Jan/Jun 2013

Doc. 5

ISSN 2179-135X

DOI: http://dx.doi.org/10.12660/gvcasosv3n1c5

\title{
THE RECENT HISTORY OF FINANCIAL INCLUSION IN AUTAZES ${ }^{1}$
}

RENE BIROCHI - rene.birochi@ unisul.br

Unisul - Universidade do Sul de Santa Catarina, Florianópolis - SC, Brasil

Jahan Ara Peerally - jahan.peerally@ hec.ca

HEC Montréal, Montréal, Canada

MARLEI Pozzebon - marlei.pozzebon@ @hec.ca

HEC Montréal, Montréal, Canada

Submissão: 05/12/2012 | Aprovação: 03/04/2013

\begin{abstract}
Financial inclusion brought benefits and challenges to Autazes, a remote municipality in the Amazon. Could a more holistic, integrated view of both financial inclusion and the role of ICT (information and communication technology) bring a different result?

This case was primarily designed to be used in graduate classes dealing with the intersection of two broad areas: ICT4D (information and communication technology for development) and social inclusion.
\end{abstract}

Keywords: Financial inclusion, Socio-economic development, Development, Communication technology.

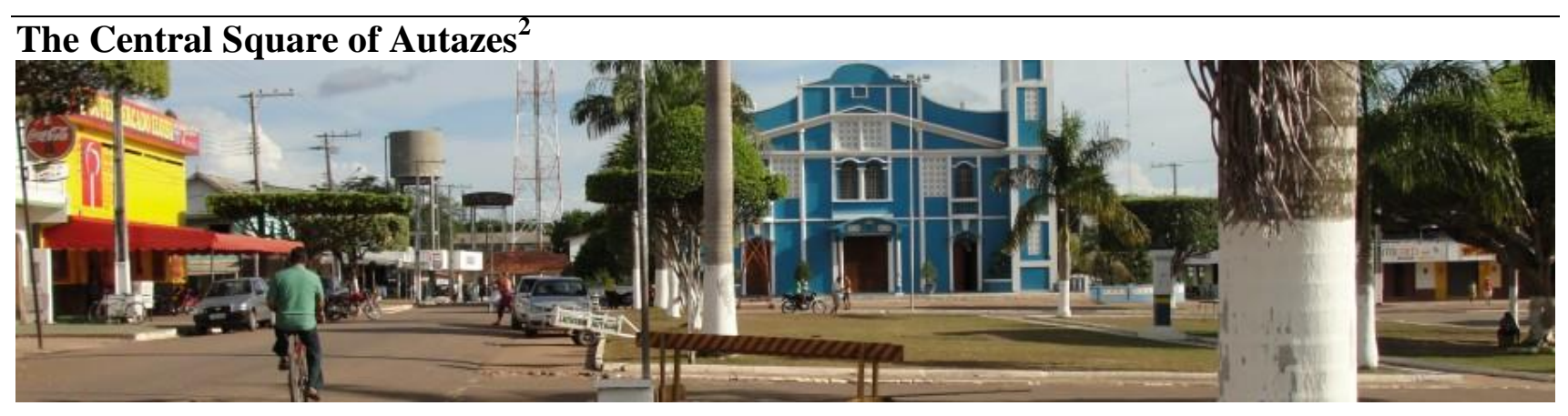

\footnotetext{
${ }^{1}$ We would like to thank Frederic Lavoie, Melissa Simao-Irala and Fabio Prado Saldanha for their precious work as research assistants in the translation and edition of this case. We would like to thank Eduardo Diniz and his team of students and collaborators: Ivan Moura and Solly Sayeg. We would like to thank IDRC (International Development Research Center), SSHRC (Social Sciences and Humanities Research Council) and CNPq (Conselho Nacional de Desenvolvimento Científico e Tecnológico - 'National Counsel of Technological and Scientific Development') for their financial support to the research program within which this case was produced.

${ }^{2}$ All pictures are from the authors.
} 
Born and raised in Autazes $^{3}$, Silvino Correia is a 78-year-old retired fisherman. Every afternoon since he retired in 1992, he'll walk to the town's central square to meet his friends, play domino, watch passers-by, and chat about the good old days.

However, on the last day of each month - his pension payday - Silvino and his friend have another gathering spot - the queue at Banco Postal where they collect their pensions. Then, Silvino will go to a local grocery and do his shopping for the month. Occasionally, he will also stop by a clothing store and get something for himself.

This mundane end-of-month routine used to be a lot more complicated for Silvino and his friends.

\section{Silvino playing domino with his friends}

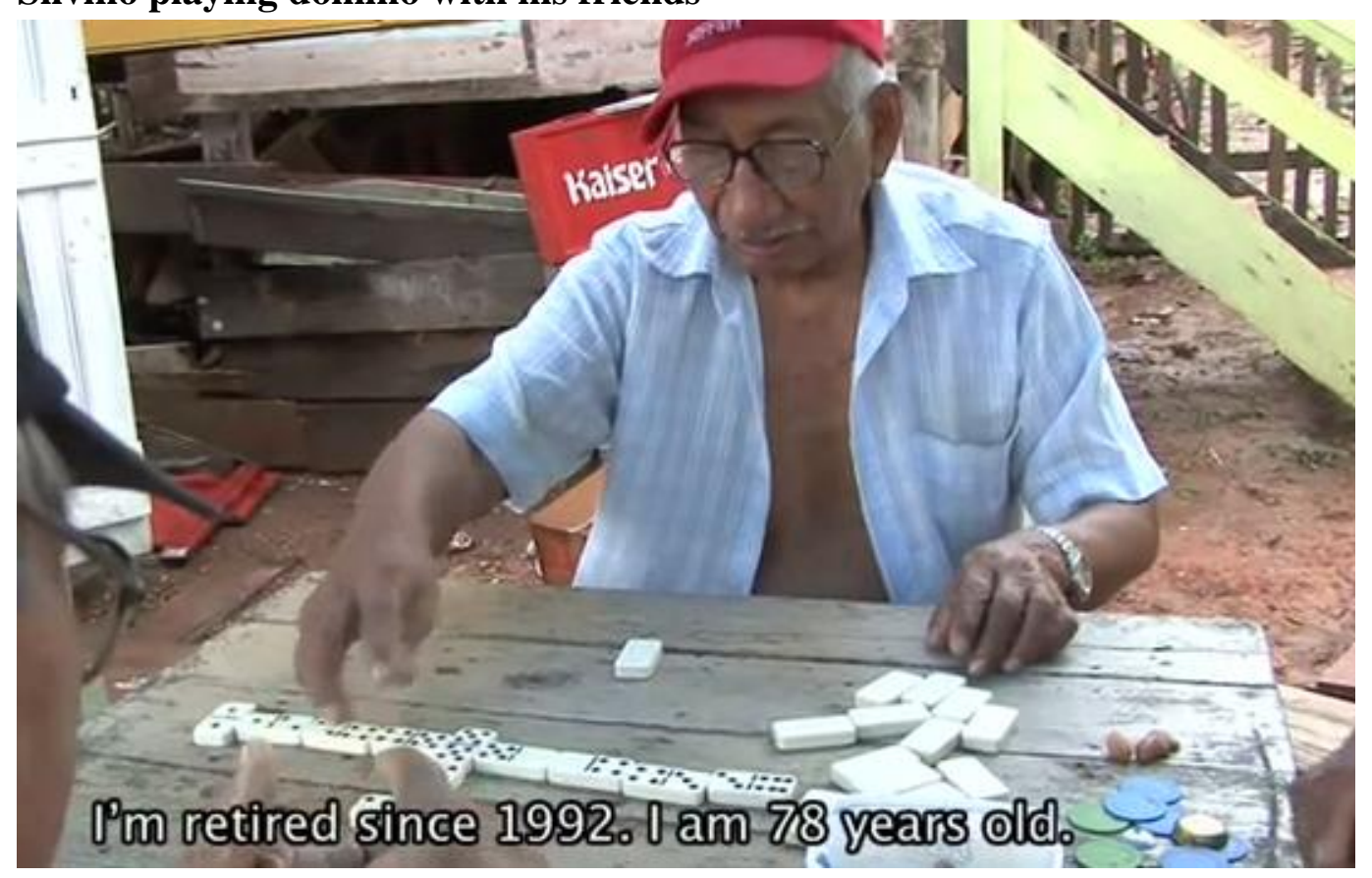

http://tinyurl.com/autazes1

\section{Pre-2002: Dealing with financial exclusion in Autazes}

When Silvino retired, no financial services were available in Autazes, which forced him to travel each month to Itacoatiara, a village $411 \mathrm{~km}$ (255 miles) away from Autazes, in order to collect his pension. He would hop on a boat at 9 am and arrive in Itacoatiara at $4 \mathrm{pm}$, but by then the banks were closed. Consequently, he ended up having to spend the night in Itacoatiara to collect his money the next day.

Because Itacoatiara's trade was more developed and varied than in Autazes, and because Silvino and his fellow pensioners pocketed their money in that village, they'd eventually make all their shopping there before returning home. So however unintentionally, Silvino and his companions were contributing to develop Itacoatiara's local trade.

\footnotetext{
${ }^{3}$ Please see Appendix 1 for further information on Autazes.
} 
Autazes' lack of financial services also forced its citizens to travel to Manaus - the capital of Amazonas State - or to Itacoatiara ${ }^{4}$ for both shopping and accessing basic banking services, such as cash withdrawals, deposits, and paying bills. Silvino's friends would often travel to Manaus to withdraw their cash. Going to Manaus, his friends complained, was a waste of working hours and money, as the 12-hour trip cost at least R $\$ 38$ (US\$19) ${ }^{5}$.

Those who couldn't afford the journey - most of the Autazes' population - would ask a friend or a relative who was going to the capital, or even the boat pilot, to handle bank transactions for them. Some would even pay an intermediary for that purpose, which made them vulnerable to loss and theft. In addition, the cash movement between the two cities attracted thieves. As Percilei Pantoja, then vice-mayor of Autazes, commented: "There was a person here who charged from $R \$ 10$ to $R \$ 20$ [US\$5-10] to pay people's bills in Manaus. Sometimes the money disappeared, the guy was robbed" "Others would make deals with retailers in the capital whereby the clients provided their names, bank details and addresses, and the retailers would withdraw the necessary amounts and deliver orders to the clients' homes.

\section{Travelling by boat to Manaus from Autazes}

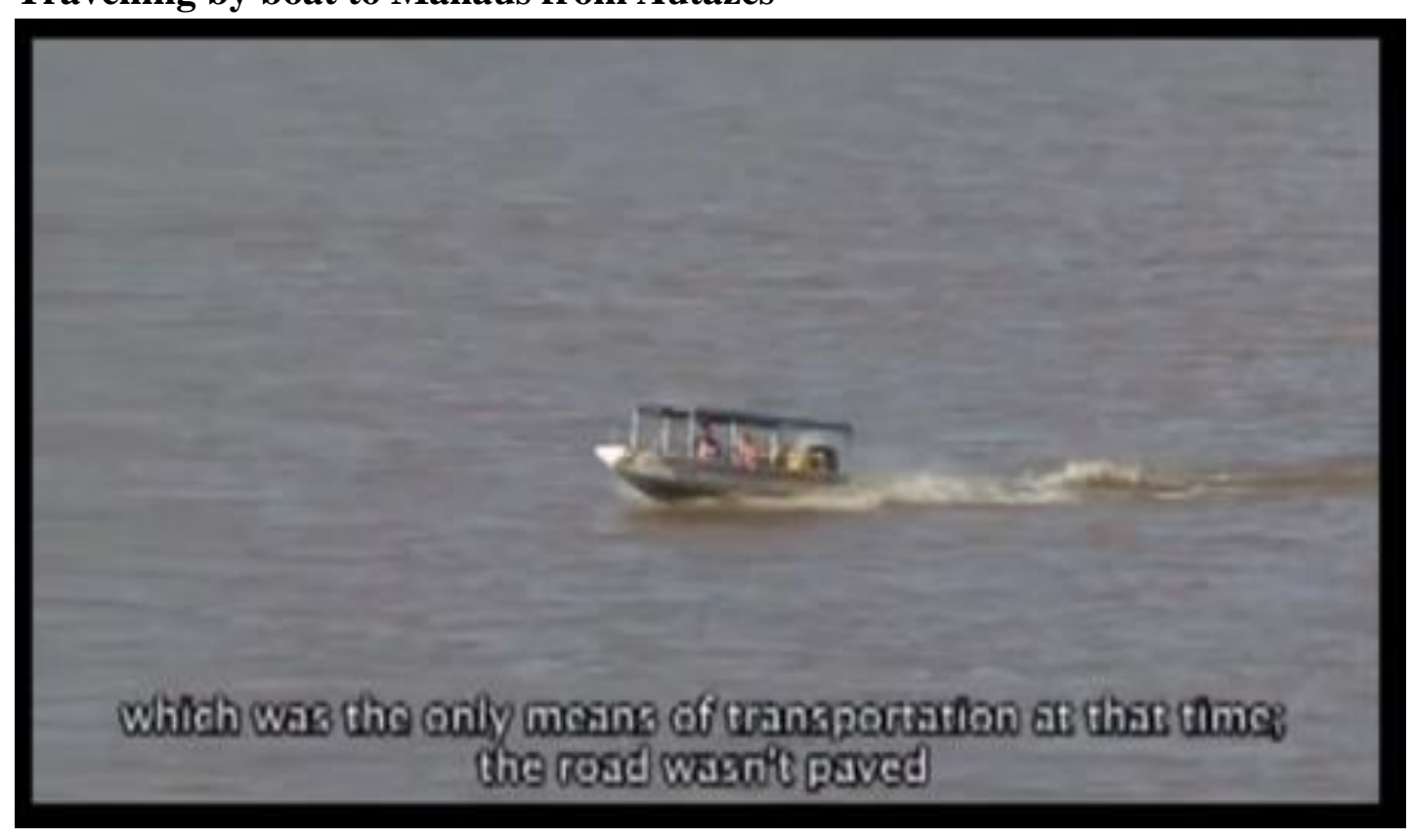

http://tinyurl.com/autazes2

The lack of financial services in Autazes also meant high costs for the municipal authorities in order to pay the salaries of public employees. Until 2002, these employees received their monthly salaries through an agent who flew in from Manaus with a suitcase containing an impressive

\footnotetext{
${ }^{4}$ Both cities had baking services available and were the nearest locations to Autazes with access to financial services.

${ }^{5}$ Currency conversion July $2012=$ US $\$ 1=\mathrm{R} \$ 2.04$. This exchange rate was applied to the entire case.

${ }^{6}$ Valor Online, "Inclusão bancária: Salário de servidor agora pode ser pago na cidade" (Banking inclusion: salary of public service public employee can now be paid in the city). Wednesday, November 10, 2004. Retrieved on August 7 , 2009, from

http://www.valoronline.com.br/veconomico/?show $=$ index $\&$ mat $=2686842 \&$ edicao $=970 \&$ caderno $=93 \&$ news $=1 \&$ cod $=99$ $\underline{6 \mathrm{e} 175 \mathrm{~b}}$
} 
$\mathrm{R} \$ 300,000$ (US $\$ 150,000$ ) in cash. Security guards were hired to escort the agent from Manaus to the Autazes City Hall, where the employees were paid. The local government was spending a monthly $\mathrm{R} \$ 3,000$ (US\$1,500) just on the security of these operations.

Despite receiving their salaries in Autazes, most public employees would also travel to Manaus to enjoy greater product variety at lower prices, or simply to deposit their salaries in their bank accounts.

Therefore, with citizens spending most of their money in the capital or in Itacoatiara, Autazes' economy was being negatively impacted, as the situation reduced the liquidity available, hindering the development of local businesses.

\section{Bankarization of Autazes since 2002}

The process of bankarization (i.e., access to and use of banking services) began in Autazes in 2002, initially with the introduction of bank correspondents, and eventually with the opening of an actual bank branch.

Simply put, correspondent banking involves arrangements between banks and non-bank entities - typically retail and services businesses, such as gas stations, post offices, stores, drugstores, etc. - where the non-bank entities agree to operate as a financial service provider. These retail businesses implement ICT-based point-of-sale devices or basic personal computers functioning as financial transaction terminals ${ }^{7}$. At these terminals, clients can pay their bills, open bank accounts, make deposits and transfers, access credit products, get bank statements and balances, and withdraw government benefits ${ }^{8}$. According to the Central Bank of Brazil, the purpose of correspondent banking is: "...to provide specific services (...) and (...) offer financial products in remote locations" (Banco Central do Brasil, 2009) 9 .

By July 2009, Autazes had six businesses offering correspondent banking services and one bank branch.

\section{Correspondent Banking}

\section{Banco Postal}

Banco Postal (Appendix 2) was the first banking correspondent to open in Autazes, in 2002. It was created in 2001 when a Brazilian private bank won a public bidding opened by the national post service to provide financial services in remote locations across the country. The creation of Banco Postal included a partnership between the private bank and the Brazilian Post and Telegraph Corporation (ECT) under which ECT operated correspondent banking activities for the private bank in post offices across Brazil.

During the time that Banco Postal was the only banking services provider in Autazes, Silvino had to line up for hours on paydays to receive his pension or withdraw money. The reason was that

\footnotetext{
${ }^{7}$ DINIZ, Eduardo; POZZEBON, Marlei \& JAYO, Martin. (2009) "The Role of ICT in Helping Parallel Paths to Converge: Microcredit and Correspondent Banking in Brazil". Journal of Global Information Technology Management (JGITM), Special Issue on "Information Technology Research in Brazil", 12 (2), April 2009.

${ }^{8}$ Thompsom, C.E.M., Barbosa Júnior, C.L., Frota, I.L.N. “A parceria Bradesco e Correios no Banco Postal: uma abordagem estratégica, tecnológica e social” (The partnership between Bradesco and Correios: a strategic, technological and social approach), in X Simpósio de Engenharia de Produção, Bauru, Brazil, 2003.

${ }^{9}$ Source: Banco Central do Brasil (available at www.bcb.gov.br/pre/SeMicroInter2/Palestras/05_1_Ceofas.pdf ).
} 
Banco Postal had only five tellers for a population of over 31,000. Even if they had hired additional staff, lines would still be inevitable. Access to financial services would suffer whenever an incident blocked money transfers from Manaus, or when satellite communication was down, making it impossible for Banco Postal to provide basic banking transactions.

\section{Banco Expresso}

The three businesses offering Banco Expresso's banking services in Autazes are: Supermercado Leida, Supermercado Eloisa, and WR Confecções. Citizens can make deposits and withdraws and pay bills - the most common transactions - at these retailers.

At Supermercado Eloisa (Appendix 3), with its nearly 300 banking transactions on paydays, the owner said that transaction fees were a significant incentive to act as a banking correspondent. In fact, the number of payday transactions is so high that the store has to allocate an employee just to manage them. The owner also noticed an increase in sales due to the larger number of people coming in for the transactions.

On the other hand, the manager at Supermercado Leida (Appendix 4) said transaction fees were not so relevant to them, probably because the store made fewer transactions than Supermercado Eloisa. However, the manager referred a $50 \%$ increase in sales due to the increase in clients' visits. Yet he believed the main benefit of acting as a banking correspondent was to offer clients the opportunity to make financial transactions, relieving the long queues at the bank branch.

The owner of WR Confecções (Appendix 5) also said that transaction fees were not significant to his business, but added he didn't notice any sales increase. Again, a possible cause is the lower number of transactions.

\section{Lotérica}

The lottery retailer Lotérica Auta Sorte (Appendix 6) acts as a banking correspondent for two Brazilian public banks: Caixa Econômica Federal and, since 2008, Banco do Brasil. Users and employees at Lotérica stress two major problems with the banking services offered there. Firstly, Lotérica keeps a low cash reserve, which significantly limits users' day-to-day withdrawals, forcing many of them to return the next day in order to complete a withdrawal. Secondly, on benefit paydays, Lotérica's infrastructure is insufficient for the surging demand. Users described cases of elderly women from distant areas who had travelled a whole day just to find a long waiting line, which forced them to stand and wait, making their journeys even more painful.

\section{Technological difficulties}

These banking correspondents faced two common problems related to the technological platform, which consists of two devices connecting the terminals (point-of-sale devices - Appendix 7) to the bank via the Internet and phone lines. First, the correspondents experienced regular difficulties in connecting to the network because of the region's instable telephone and Internet systems. Second, the high demand on paydays overloads the network, causing indefinite downtime 
in the whole system. These technological problems were the main reasons why several users avoided banking transactions at these correspondents.

\section{Banking branch}

The challenges related to the large number of users in the city and the long waiting lines at Banco Postal led the same private bank that created Banco Postal to open a branch in Autazes in 2007. This bank also installed three more banking correspondents in the city under Banco Expresso's trademark.

\section{Access to credit and other financial services \\ Credit}

The bank branch offers credit in the form of consigned loans. Clients usually apply for consigned loans for home remodeling - for example, replacing a wooden structure with a bricked one. The branch also finances nearly half of motorcycle sales in the city.

According to the branch manager, loans generally have a low default risk. He explains that clients are willing to repay their loans and that when they can't, they'll send a letter, call or send messages through friends, informing the bank in advance about their difficulty to make a payment in a specific month.

\section{Microcredit}

Microcredit in Autazes is provided by two public organizations: the Agency for the Promotion of the State of Amazonas (AFEAM); and the National Program for Strengthening Family Agriculture (PRONAF), which is federally supported through the Ministry of Agrarian Development.

AFEAM is a non-bank financial institution created to promote socio-economic development in the State of Amazonas by providing credit and technical support, in order to facilitate income and employment generation and improve the living standard of the State's population. Among AFEAM's several funds and programs is the Fund for the Support of Micro and Small Enterprises and the Social Development of the State of Amazonas (FMPES). This fund provides financing for machinery, equipment, working capital, targeting micro and small enterprises in the industrial, commercial and service sectors with a minimum three years of operation. In fact, most of the city's 70 public market vendors already have a loan from AFEAM or intend to apply for one.

The organization charges low annual interest rates ranging from $7-10 \%$ and gives a $25 \%$ bonus to non-defaulting beneficiaries. However, default rate is significantly high at $37 \%$. According to AFEAM's manager in Autazes, the default problem has two main reasons: some beneficiaries don't feel as pressured to repay public funds as they would with private bank loans; others fail to efficiently manage the microcredit obtained. Because of the latter, AFEAM has decided to require beneficiaries to take a 24-hour training course. The training covers entrepreneurship, marketing, publicity, competition, and supplier and client relationships.

Created in 1995, PRONAF is a government program designed to provide financial support to farmers and their families in both farming and non-farming activities ${ }^{10}$. Therefore, PRONAF's

\footnotetext{
${ }^{10}$ Ministério do Desenvolvimento Agrário, Portal da Secretaria da Agricultura Familiar (Ministry of Agrarian Development, Secretary of Family Farm website portal)
} 
microcredit allows farmers to expand into new farming and non-farming income-generating activities, as well as acquire machinery, equipment, seeds and inputs.

PRONAF's annual interest rate, which varies from $0.5 \%$ to $4.5 \%$, is the lowest in the country for rural financing. Like AFEAM, PRONAF also provides a $25 \%$ bonus for timely repayment. The program's default rate of approximately $2.5 \%$ is also impressively low, considering the large number of beneficiaries across the country.

\section{The blurred line between consigned credit and microcredit}

In Autazes, a disturbing situation has emerged involving both consigned credit and microcredit. Microentrepreneurs with informal productive activities and no collateral are not eligible for the branch's cosigned loans or AEAM and PRONAF's microcredit. In fact, informal microentrepreneurs are locked out of Autazes' credit system.

To overcome this locked-out situation, these microentrepreneurs resort to relatives and friends - such as public service employees and pensioners - people with some collateral and a regular formal income. These relatives and friends apply for a consigned loan at the bank branch and then pass it over to the microentrepreneurs.

Apparently, this is a significant means for microentrepreneurs to finance their businesses in Autazes. Therefore, the credit provided through consigned loan is actually serving to finance microentrepreneurs' informal productive activities.

This phenomenon has two dire consequences. Firstly, it falsely biases the demand for microcredit and consigned loans in Autazes. Therefore, microcredit demand appears lower while consigned loan demand appears higher than they actually are. Moreover, this situation affects official statistics making it impossible to accurately set the amounts that should be allocated to consigned loan and productive microcredit in the city.

Secondly, consigned lending can result in borrower over-indebtedness, despite the Brazilian Federal Act 10.953 which determines that only $30 \%$ of a person's income can be considered for loan repayment purposes ${ }^{11}$. Over-indebtedness occurs because no unified system exists to control credit offer in Autazes. Without such a system, citizens can ask for, and be granted a loan at several institutions at the same time. In these cases, loan payments add up to more than $30 \%$ of the borrower's income. Many people in Autazes have as much as $90 \%$ of their income committed to payments of several, simultaneous loans to help microentrepreneurs.

\section{Additional services offered by the bank branch}

Autazes population's demand is low for other types of financial services from the bank branch.

Firstly, there is little demand for savings accounts. The main reason is that, whether in urban or rural areas, few people in the city earn enough to save. Those who do earn enough prefer to keep their money at home, since they don't trust the bank.

\footnotetext{
${ }^{11}$ For more information, visit: http://www.planalto.gov.br/ccivil_03/_ato2004-2006/2004/lei/110.953.htm; http://jus.com.br/revista/texto/13780/emprestimo-consignado-em-folha-de-pagamento; or http://www.emprestimoconsignado.com.br/lei-do-emprestimo-consignado/
} 
Secondly, there is little demand for insurance policies because the people of Autazes don't feel that they need insurance or don't understand the benefits of having one. Nevertheless, the bank branch offers two types of policies: a life insurance for R \$9.90 (US\$5.65) per month, and a funeral insurance for R $\$ 25$ (US\$14.25) per month.

Thirdly, despite the branch's efforts in a large campaign to introduce debit and credit cards in the city, demand remains low. Again, the population's resistance to, or lack of understanding of banking services is the most likely reason.

\section{Bankarization in the perspective of Autazes citizens}

Following the bankarization of Autazes, afternoons became increasingly busy and crowded downtown. Silvino observed that more people were walking around in the central square. New stores opened, old ones were remodeled, and even the fish market increased its sales. The variety of locally offered products and services also increased, which led to more people shopping in the city instead of going to Manaus or Itacoatiara. Business owners felt encouraged to invest in Autazes, as more wealth was now circulating in the city (Appendix 10). André Cano, a former superintendent at Banco Postal, commented: "Banco Postal is bringing progress to thousands of municipalities that have been underserved by the traditional financial system", 12 .

\section{Shopkeeper describing local circulation of money in Autazes}

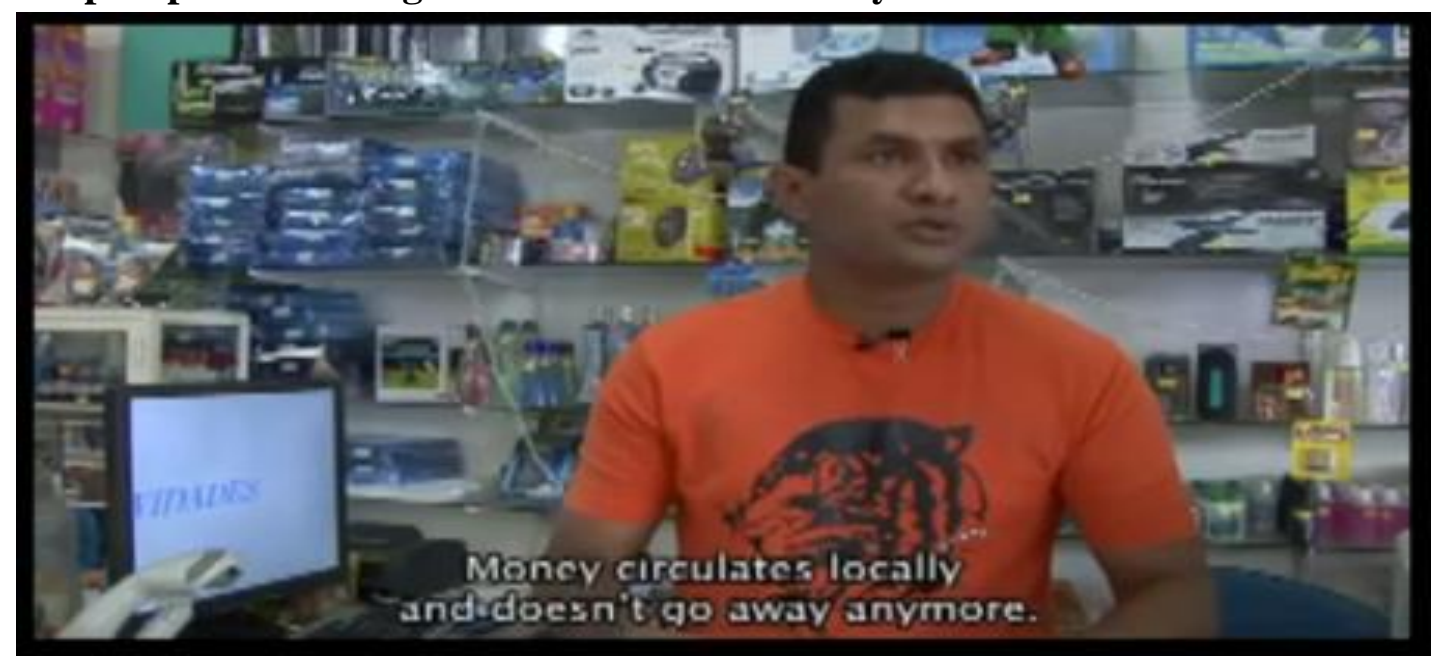

http://tinyurl.com/autazes3

In addition to making withdrawals and deposits or paying bills, the citizens of Autazes could now apply for loans in their own town. Initially, these applications were made at Banco Postal in Autazes, where a bank employee from Manaus would periodically collect them for evaluation in the capital. Nowadays, with a bank branch in the city, all applications are locally handled and evaluated.

\footnotetext{
12 Valor Online, "Inclusão bancária: Correspondentes ativam economias locais, atraindo comércio e novos investimentos" (Banking inclusion: Correspondents boost local economies by attracting trade and new investments). Wednesday, November 10, 2004. Retrieved on August 7, 2009, from http://www.valoronline.com.br/veconomico/?show $=$ index \&mat $=2686842 \&$ edicao $=970 \&$ caderno $=93 \&$ news $=1 \&$ cod $=99$ $\underline{6 \mathrm{e} 175 \mathrm{~b}}$.
} 
THE RECENT HISTORY OF FINANCIAL INCLUSION IN AUTAZES

Rene Birochi, Jahan Ara Peerally, Marlei Pozzebon

In addition, local public servants have access to a bank account at Banco Postal where their monthly salary is credited and can be withdrawn. To the municipality, it also meant the end of high security costs with salary cash transfers from Manaus to Autazes. The local government also benefitted from higher revenues from service taxes. In short, the municipality was enjoying a surge in economic development.

\section{Local resident describing economic growth in Autazes}

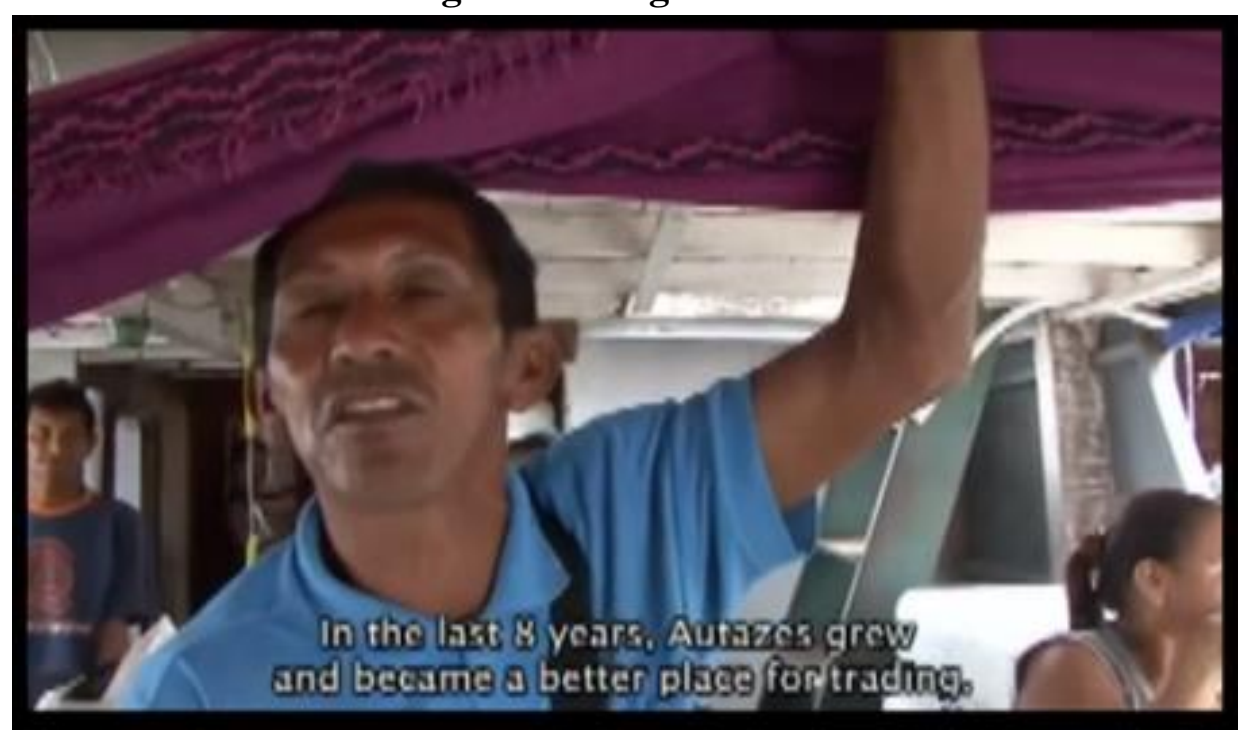

http://tinyurl.com/autazes4

Despite the progress in the city, Silvino has noticed from his conversations with relatives and friends, that most of them have a negative image of the bank branch and the private bank that drove Autazes' bankarization. Because the private bank that introduced correspondent banking and the branch in Autazes is financially strong, the citizens perceive it as not very trustworthy and financially "predatory". Others believe that public banks - such as Caixa Econômica Federal and Banco do Brasil - are more trustworthy for making less profit than the private institution. These perceptions lead to a certain resistance to the bank branch, with users expressing a feeling of being cheated. One example of this resistance is the following comment of one citizen: "I use that bank as a first-aid fix, just because I don't have any alternative".

This sense of being cheated appears in several anecdotes told by local citizens. Some suggest, for example, that the branch - and private banks in general - was committing "robbery" by deliberately offering debit and credit cards, especially to retired people, with the sole intent of charging them for their use. A shopkeeper said that issuing credit cards in the city has become a profitable business for the bank branch. Another anecdote was told by one of the branch's clients: "In about two days, the bank took $R \$ 57$ (US\$32.50) off my money in overdraft and card fees even though I don 't use any of that". Another client added: "In the bank, my money disappears within two days".

The atmosphere of suspicion has remained because the branch isn't committed to ensuring that clients, especially retired ones, avoid the risk of over-indebtedness when applying for, and receiving loans. 
These negative perceptions, though not fully justified, are expressed because the people of Autazes don't fully understand the reasons why the branch should charge fees for some of its services. These perceptions, plus the waiting lines and the branch's bureaucratic requirements and formalities, all adds to the feeling that the bank disrespects the population of Autazes.

\section{Progress is not universal in Autazes}

The implementation of the bank branch and correspondents, and the resulting consolidation of a financial system in Autazes since 2002 had a significant impact on the development of specific economic sectors. Data from the Brazilian Institute of Geography and Statistics on Autazes' GDP between 2002 and 2006 indicate a growth rate for the period of 90\% in the services sector, 87\% in the industrial sector, and $25 \%$ in the farming sector. The impact is also very clear to many Autazes citizens who recognize that this progress is due to the recent offer of financial services in the city.

However, progress has not occurred universally across Autazes, with 40 communities in the city still lacking access to banking services. In order to pay bills, make withdrawals, or receive government benefits, the rest of the population has to travel to the city's urban center. Therefore, the phenomenon of Autazes' wealth circulation in Manaus and Itacoatiara in the past can still be seen in the municipality's rural communities. Only instead of Manaus and Itacoatiara, today the liquidity of rural communities circulates in the urban center of Autazes.

Novo Céu, the largest rural community in Autazes, faces a situation that is particularly similar to that of Autazes before 2002. The community's population travels to town in order to make basic financial transactions. As a result, they make their shopping there because of the greater offer and lower prices. Therefore, the community's liquidity is being largely spent in Autazes.

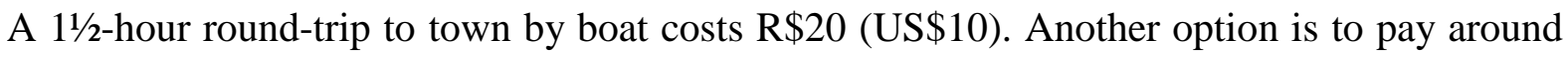
$\mathrm{R} \$ 10-20$ (US\$5-10) for an intermediary to make basic financial transactions in Autazes. Business owners in Novo Céu perceive the lack of banking services and the locals' need to go into town as a significant obstacle to local businesses' development. There used to be a banking correspondent in a small grocery store in Novo Céu. However, the correspondent was shut down when the store was sold. A few business owners argue that the shutting down of the correspondent had a negative, immediate impact on their sales. In addition, the community's population believes that the lack of banking services means extra costs for businesses and citizens in general, just like with Autazes before 2002 .

\section{Conclusion}

In Autazes, different organizations with equally different objectives have increased the population's access to financial services. On one hand, there is the private bank (through its branch and correspondents), which has expanded and diversified its client base and services to increase profitability. On the other hand, there are the public organizations - AFEAM and PRONAF providing microcredit for the low-income population in order to foster economic development in the municipality.

Despite its focus on profits, the private bank's branch and correspondents have indirectly contributed to developing Autazes' local economy. However, the bank branch doesn't consider 
microcredit a financially viable service and continues to focus on consigned credit as the only viable product.

By offering microcredit at subsidized interest rates through programs such as AFEAM and PRONAF, the State Government hopes to foster continued development in the municipality. However, these programs suffer from their own limitations, including the fact that public funds distribution between the State's municipalities is subject to political lobbying.

\section{Life goes on for Silvino and friends...}

One fine payday afternoon, Silvino meets a friend - a retired man from Novo Céu - at Banco Postal. After both have collected their pensions, Silvino invites the man to join him and his group at the Autazes' central square for a few rounds of domino. At the square, as the first round begins, the old friend from Novo Céu voices to no one in particular that he wishes a branch would open soon in his neighborhood because he is tired of his monthly traveling to town. On hearing this, one of the group - a fisherman, over-indebted like all other fishermen in Autazes - exchanges a dubious glance with the others. 


\section{Appendix 1}

A background of Autazes

Autazes, officially discovered in the $18^{\text {th }}$ century, was historically inhabited by Mura Indians, famous for their great resistance to the Portuguese colonization. The region was named many years ago after the two rivers draining its lands: Autaz-Açu and Autaz-Mirim.

The municipality of Autazes, which covers approximately $7,600 \mathrm{~km}^{2}$ (roughly $0.5 \%$ ) of the State of Amazonas ${ }^{13}$, was created in 1955 and is located in the region of Rio Negro-Solimões in the heart of the Amazon forest. Located some 96 kilometers way from Manaus, the State capital, Autazes is not easily accessible. In good weather conditions, it can be reached within two and a half hours through a boat-car-boat combination; otherwise, it can be a twelve-hour boat journey.

Today, Autazes has 32,135 inhabitants, ${ }^{14}$ some 14,000 of which live in the urban area. The municipality includes 40 communities, such as Rosarinho, Sampaio, Urucurituba, Miguel, Novo Céu, Mastro, Rochedo, Baracuba, Cara Grande, Rio Preto, Gomo, Butuca and Ramal do Ferro Quente. Novo Céu and Sampaio are the most populous communities in the rural area, with 6,000 and 600 inhabitants respectively.

Autazes' GDP - mostly derived from farming activities - reached R $\$ 136$ million (roughly US\$68 million) in 2009 , accounting for $0.33 \%$ of the State's GDP and ranking $17^{\text {th }}$ among the State's 62 municipalities. The city's Human Development Index (HDI) is 0.661 (data for 2000), ranking 19th among all cities in the state of Amazonas. ${ }^{15}$

\footnotetext{
${ }^{13}$ IBGE@CIDADES. Autazes. Retrieved on August 06, 2012, from http://www.ibge.gov.br/cidadesat/link.php?codmun=130030.

${ }^{14}$ IBGE@CIDADES. Autazes. Retrieved on August 06, 2012, from http://www.ibge.gov.br/cidadesat/link.php?codmun=130030.

${ }^{15}$ ONU - Organização das Nações Unidas. Novo Atlas de Desenvolvimento Humano no Brasil, Brasília, 2002.
} 


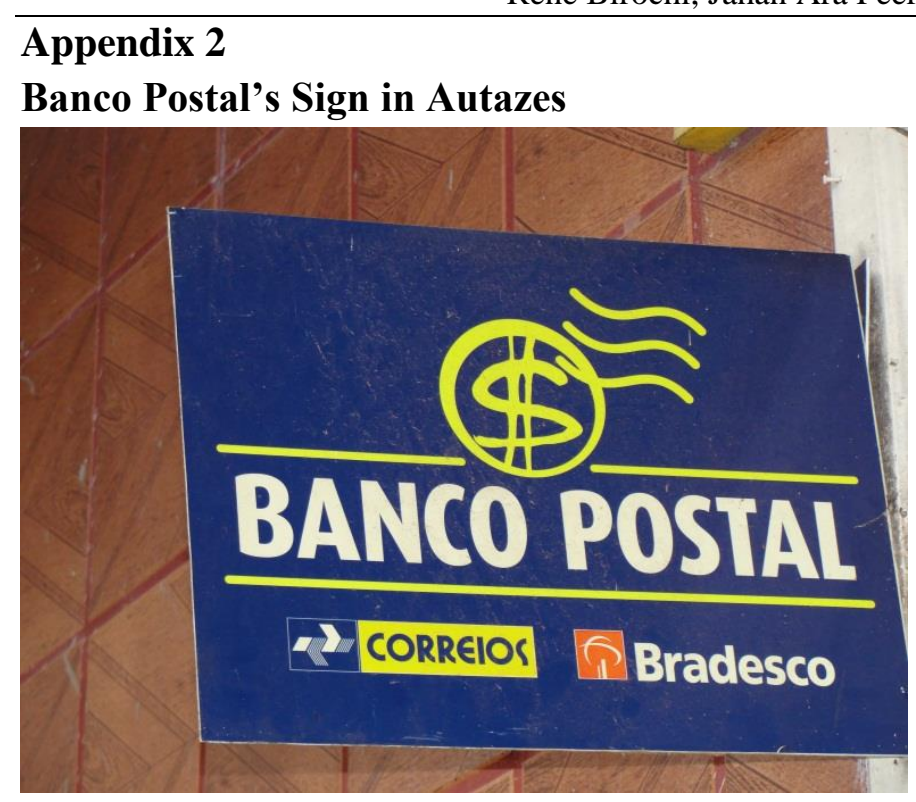

\section{Appendix 3}

\section{Supermercado Eloisa}

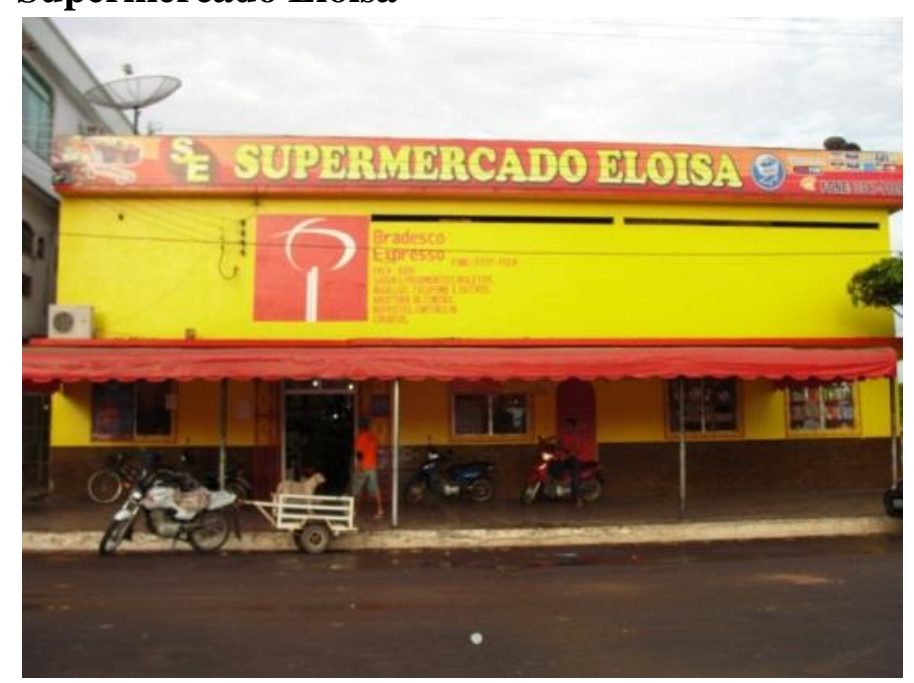




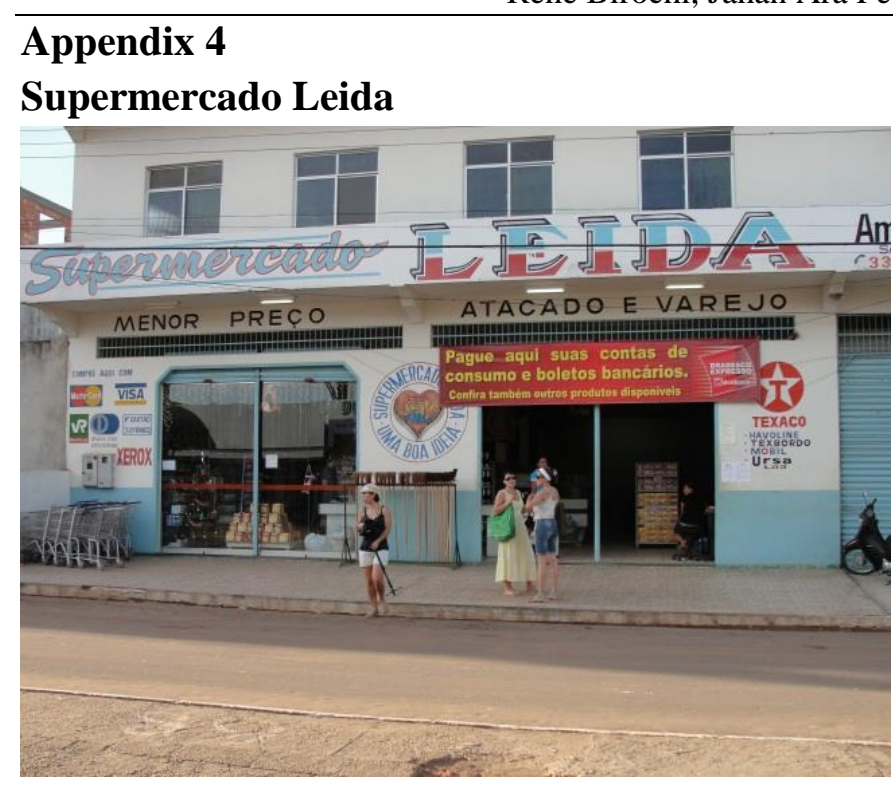

\section{Appendix 5}

\section{WR Confecções}
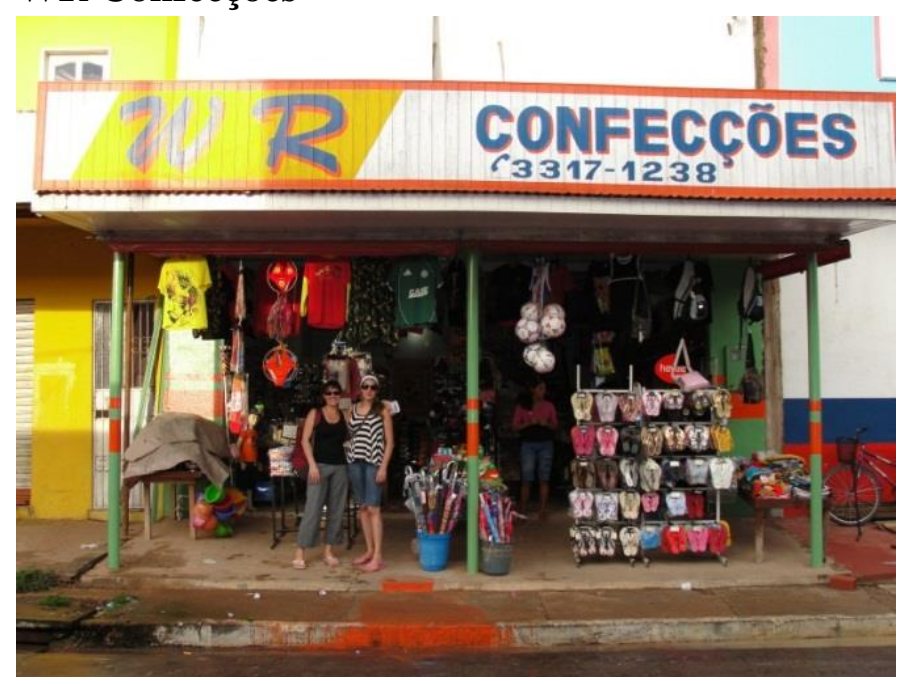
THE RECENT HISTORY OF FINANCIAL INCLUSION IN AUTAZES

Rene Birochi, Jahan Ara Peerally, Marlei Pozzebon

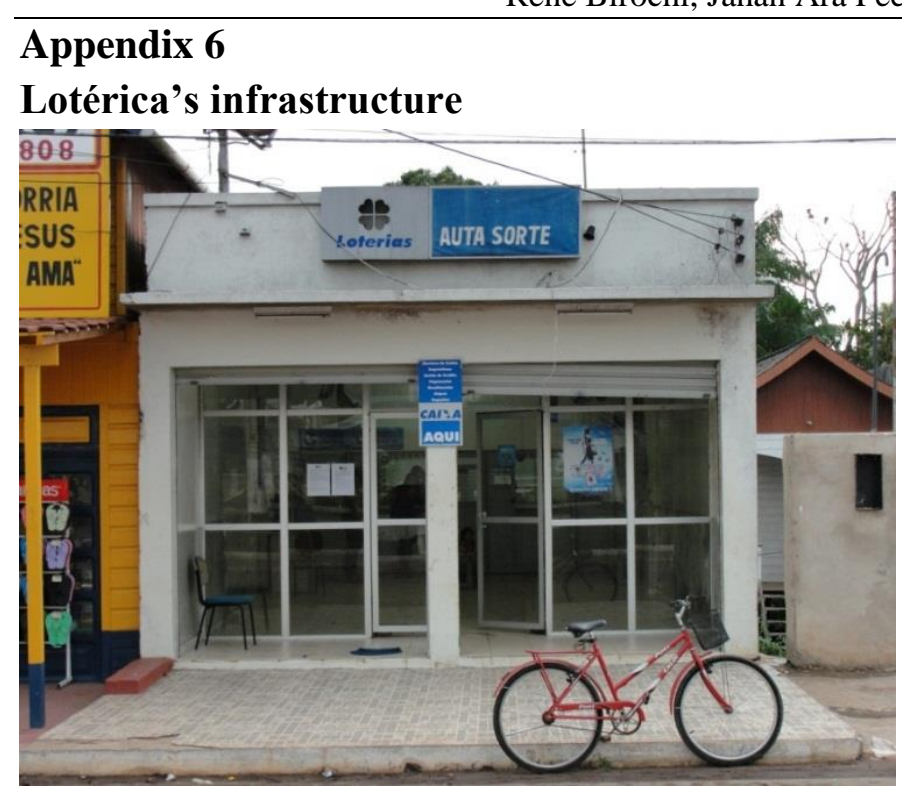

\section{Appendix 7}

\section{Point-of-sale devices}

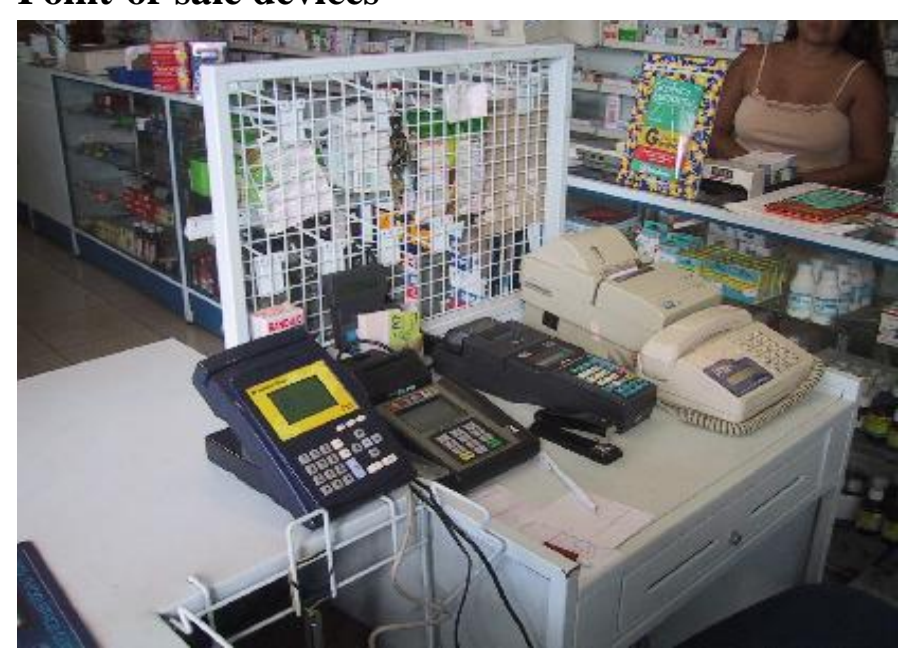

